\title{
Dual natural infection with bovine viral diarrhea virus -1 and -2 in a stillborn calf: tissue distribution and molecular characterization
}

\author{
Maximiliano J. Spetter ${ }^{1,2, \$}$, Enrique L. Louge Uriarte ${ }^{2, \$}$, Erika A. González Altamiranda ${ }^{2,3}$, María R. Leunda $^{2}$, \\ Susana B. Pereyra ${ }^{2}$, Andrea E. Verna ${ }^{2,3}$ and Anselmo C. Odeón ${ }^{2, *}$ \\ ${ }^{1}$ Fondo para la Investigación Científica y Tecnológica (FONCYT), Godoy Cruz $23702^{\circ}$ piso, Buenos Aires \\ (C1425FQD), Argentina \\ ${ }^{2}$ Grupo de Sanidad Animal, Área de Producción Animal, INTA EEA Balcarce, Ruta 226, km 73.5 (CP 7620), \\ Argentina \\ ${ }^{3}$ Consejo Nacional de Investigaciones Científicas y Técnicas (CONICET), Avenida Rivadavia 1917, Buenos Aires \\ (C1033AAJ), Argentina \\ ${ }^{\star}$ Contributed equally to this work
}

\begin{abstract}
Dual infections with both bovine viral diarrhea virus (BVDV)-1 and -2 seem to be unusual. The aim of this study was to describe an infection with both BVDV genotypes in a stillborn calf. Virus isolation and phylogenetic analyses of the 5'UTR and NS5B regions confirmed the presence of BVDV-1b and $-2 b$ in spleen and lung, whereas BVDV-2b was also detected in brain, heart, liver, kidney and, fluid of cavities. These results confirm that dual infections with both BVDV-1 and BVDV-2 species can occur naturally and their tissue distribution can be different.

Keywords: Bovine viral diarrhea virus, Co-infection, Phylogenetic analysis.
\end{abstract}

\section{Introduction}

Bovine viral diarrhea virus (BVDV) is a significant cause of economic losses in the cattle industry worldwide. BVDV (family: Flaviviridae, genus: Pestivirus) can be divided into two species, BVDV-1 and BVDV-2 (Ridpath et al., 1994). BVDV-1 and -2 are present in Argentinean bovine herds (Jones et al., 2001; Odeón et al., 2003; Pecora et al., 2014), being BVDV-1b the predominant specie (Pecora et al., 2014). The genetic typing of BVDV strains can help in the investigation of BVDV outbreaks (Vilcek et al., 2005) and the classification into species and subgenotypes is widely based on the 5'UTR, Npro, and E2 genomic regions (Nagai et al., 2004; Vilcek et al., 2005).

Infection in pregnant females with BVDV results in a variety of reproductive losses, such as infertility, embryonic death, fetal malformations, abortions, stillbirths, and the birth of weak calves (Baker, 1995). Transplacental infections with the non cytophatic (ncp) BVDV strain between days 40 and 120 of gestation causes the birth of persistently infected (PI) animals (Grooms, 2004). These PI animals are the main source for BVDV transmission in cattle population because they shed large amounts of virus during their lifetime (Grooms, 2004).

Dual infections with more than one BVDV species have been described in fetuses and postnatal cattle either in experimental studies (Broke and Chase, 2000; Arenhart et al., 2010; Makoschey and Janssen, 2011;
Larska et al., 2012) or in natural conditions (Fulton et al., 2000; Evermann and Ridpath, 2002; Ahn et al., 2005), but only Broke and Chase (2000) detailed the tissue distribution of both species. Despite this background, fetal infections with both BVDV-1 and BVDV-2 appear to be uncommon (Makoschey and Janssen, 2011) or rarely described.

The aim of this study was to report a natural dual infection with both BVDV-1 and BVDV-2 in a stillborn beef calf that occurred in Argentina. Moreover, the tissue distribution and the genetic variability of both strains were described.

\section{Material and Methods}

An Aberdeen Angus stillborn calf was submitted for necropsy and laboratory diagnosis of abortion in 2010. The calf belonged to a beef farm located in the county of General Guido, Buenos Aires Province, Argentina. A ncp BVDV strain was initially isolated from the spleen after four blind passages on MDBK cells, whereas other relevant reproductive pathogens (Campylobacter fetus, Tritrichomonas foetus, Brucella abortus, Leptospira spp., Neospora caninum, bovine herpesvirus) were ruled out. Different tissues samples, fluids of cavities, and the cell culture supernatant of the spleen were preserved at $-80^{\circ} \mathrm{C}$ for additional studies. Further attempts of virus isolation were performed in 2017 from the brain, heart, lung, spleen, liver, and kidney samples. Also, total RNA was extracted from all the tissue samples, fluids of cavities, the respective cell 
culture supernatants, and the cell culture supernatant of the spleen from the year 2010 by using TRIzol ${ }^{\circledR}$ reagent (Invitrogen, USA) and following the manufacturer's instructions.

A nested multiplex RT-PCR (Gilbert et al., 1999), with modifications, was performed to amplify specific fragments of the NS5B genomic region. For cDNA synthesis, $8 \mu \mathrm{l}$ of RNA, $0.6 \mu \mathrm{l}(10 \mu \mathrm{M})$ of each external primer and $0.8 \mu \mathrm{l}$ of DMSO were denatured $5 \mathrm{~min}$ at $65^{\circ} \mathrm{C}$.

Thereafter, $5 \mu$ l of RT Buffer, $1 \mu$ of dNTPs $(10 \mathrm{mM}$ each, Promega, USA), $1 \mu \mathrm{l}$ (200U) of M-MLV (Promega, USA), and $3 \mu 1$ of $\mathrm{dH}_{2} \mathrm{O}$ was incubated at $37^{\circ} \mathrm{C}$ for $50 \mathrm{~min}$ and $70^{\circ} \mathrm{C}$ for $15 \mathrm{~min}$. The first round of PCR was conducted in a total volume of $50 \mu 1$ containing $2.5 \mu \mathrm{l}$ of cDNA, $5 \mu \mathrm{l}$ of $\mathrm{MgCl}_{2}(25 \mathrm{mM}), 10$ $\mu 1$ of $5 \mathrm{X} \mathrm{GoTaq}^{\circledR}$ Buffer, $1 \mu \mathrm{l}$ of dNTPs (10 mM each), $1.5 \mu \mathrm{l}$ of each external primer $(10 \mu \mathrm{M}), 0.5 \mu \mathrm{l}$ of GoTaq ${ }^{\circledR}$ DNA Polymerase (Promega, USA) and $28 \mu \mathrm{l}$ of $\mathrm{dH}_{2} \mathrm{O}$.

Cycling conditions were as follows: $1 \min 94^{\circ} \mathrm{C} ; 25$ cycles of $1 \min 94^{\circ} \mathrm{C}, 1 \min 50^{\circ} \mathrm{C}, 2 \min 72^{\circ} \mathrm{C}$; and a final step of $15 \min 72^{\circ} \mathrm{C}$. An aliquot $(5 \mu \mathrm{l})$ was used as template in the second round of PCR, which was carried out in the same manner as the first round of PCR, but $1.5 \mu \mathrm{l}$ of each internal primer $(10 \mu \mathrm{M})$ were included in the mix. The sizes of the expected amplicons were 369 bp (BVDV-1) and 615 bp (BVDV2).

Also, the second round of PCR was performed in the same conditions but only BVDV-1 specific primers were included. Additionally, a fragment from the 5'UTR genomic region was amplified from the RNA of all tissue samples and fluids of cavities using the primers 324/326 (Vilcek et al., 1994).

PCR products were resolved by electrophoresis in $2 \%$ agarose gels stained with SYBR ${ }^{\circledR}$ Green (Invitrogen, USA). The nested PCR products from the NS5B genomic region (spleen, lung, and brain tissues), and the PCR products from the 5'UTR genomic region (brain tissue and fluids of cavities) were purified with Illustra $^{\mathrm{TM}}$ ExoProStar $^{\mathrm{TM}}$ (GE Healthcare Life Sciences, UK). These amplicons were sequenced by the dideoxy chain termination method on an automated ABI PRISM 377 DNA Sequencer (Applied Biosystems Group).

Sequencing reactions were conducted in both directions using the genotype-specific primers (Gilbert et al., 1999) and the primers pair 324/326 (Vilcek et al., 1994). Consensus nucleotide sequences were assembled using the BioEdit software v7.2.5 (Hall, 1999) and the nucleotide identities of the NS5B and 5'UTR fragments were compared with cognate sequences from GenBank using the BLAST software. Phylogenetic analyses were conducted using MEGA7 software (Kumar et al., 2016).
Genetic distances were calculated using the Kimura-2 correction parameter and the phylogenetic trees were constructed using the neighbor-joining method with 1000 bootstrap replicates.

Nucleotide sequences of the 5'UTR and NS5B fragments were deposited in the GenBank database (accession numbers MH294527 to MH294529).

\section{Results and Discussion}

All tissue samples from the stillborn calf were positive for the isolation of a ncp-BVDV, even after long term (84 months) storage at $-80^{\circ} \mathrm{C}$ (Table 1 ).

The nested multiplex RT-PCR revealed that the lung tissue and the cell culture supernatant of the spleen (from 2010) contained two amplicons (369 bp and 615 bp), indicating a mixed infection by both BVDV-1 and BVDV-2, whereas the rest of the samples only contained an amplicon of 615 bp expected for BVDV2 (Table 1).

Moreover, the nested RT-PCR using only BVDV-1 specific primers revealed an amplicon of $369 \mathrm{bp}$ in the lung and spleen tissues, whereas this amplicon was not observed in the rest of the samples (brain, heart, liver, kidney, and fluid of cavities) (Table 1).

The nested RT-PCR performed on cell culture supernatants were only positive for BVDV-2, either when specific primers for BVDV-1 and BVDV-2 or only for BVDV-1 were included (Table 1).

Nucleotide sequence analyses of the NS5B fragments also confirmed the presence of both BVDV-1 and BVDV-2 in the different samples. Sequence similarities of the NS5B fragments, obtained using only BVDV-1 specific primers, revealed $100 \%$ identity between the amplicons from lung and spleen tissues, so this BVDV-1 strain was designated as 10-636 spleen/lung. Also, sequences similarities of the 5'UTR fragments showed $100 \%$ identity between the amplicons from brain tissue and fluids of cavities, so this BVDV-2 strain was designated as 10-636 brain/fc.

Table 1. Isolation and genotyping of BVDV from tissue samples and cell culture supernatants.

\begin{tabular}{|c|c|c|c|c|c|}
\hline \multirow{2}{*}{ Sample } & \multirow{2}{*}{$\mathrm{VI}^{\mathrm{a}}$} & \multicolumn{2}{|c|}{$\begin{array}{l}\text { Nested RT-PCR } \\
\text { on tissue }\end{array}$} & \multicolumn{2}{|c|}{$\begin{array}{l}\text { Nested RT-PCR } \\
\text { on supernatants }\end{array}$} \\
\hline & & $\begin{array}{l}\text { BVDV-1 } \\
\text { and }-2 \mathrm{SP}^{\mathrm{b}}\end{array}$ & $\begin{array}{c}\text { BVDV-1 } \\
\text { SP }^{\mathrm{b}}\end{array}$ & $\begin{array}{l}\text { BVDV-1 } \\
\text { and }-2 \mathrm{SP}^{\mathrm{b}}\end{array}$ & $\begin{array}{l}\text { BVDV-1 } \\
\text { SP }^{\mathrm{b}}\end{array}$ \\
\hline Brain & + & 2 & - & 2 & - \\
\hline Heart & + & 2 & - & 2 & - \\
\hline Lung & + & $1+2$ & 1 & 2 & - \\
\hline Spleen & + & 2 & 1 & 2 & - \\
\hline Liver & + & 2 & - & 2 & - \\
\hline Kidney & + & 2 & - & 2 & - \\
\hline $\begin{array}{l}\text { Fluid of } \\
\text { cavities }\end{array}$ & $*$ & 2 & - & $*$ & * \\
\hline
\end{tabular}


Phylogenetic analyses of the nucleotide sequences corresponding to the NS5B and 5'UTR fragments revealed that the strain 10-636 brain/fc (BVDV-2) was clustered within the subtype $2 \mathrm{~b}$, whereas analysis of the nucleotide sequence of the NS5B fragment showed that the strain 10-636 spleen/lung (BVDV-1) was clustered within the subtype $1 \mathrm{~b}$ (Fig 1). The 5'UTR fragment of the BVDV-1 strain could not be sequenced.

The current study provides further evidence that infections with both BVDV species can occur in natural conditions. However, to the authors' knowledge, this study reports for the first time a dual natural infection with BVDV-1 and BVDV-2 in a stillborn calf and their tissue distribution based on RT-PCR amplification. In a retrospective analysis of BVDV positive samples, Ahn et al. (2005) described the occurrence of dual natural infections in two bovine aborted fetuses (4 to 6 months of gestation).

Also, infections with both BVDV species had been reported in 2\% (2/103), 4\% (2/54) and 11\% (20/117) of the positive samples from the United States (Fulton $e t$ al., 2000; Evermann and Ridpath, 2002; Ahn et al., 2005). Few studies, under experimental conditions, have shown evidence that dual infections with BVDV1/BVDV-2 (Brock and Chase, 2000; Arenhart et al., 2010; Makoschey and Janssen, 2011) and BVDV1/Hobi-like (Larska et al., 2012) can occur, but this kind of infections could not be achieved consistently (Arenhart et al., 2010; Makoschey and Janssen 2011). In the present report, BVDV-2 was identified in more tissue samples than BVDV-1, which was only detected in lung and spleen. Furthermore, BVDV-1 could be detected in the spleen only when the primer for BVDV2 was excluded from the reaction mix. Previously, Brock and Chase (2000) characterized the tissue distribution of both species in four fetuses infected under experimental conditions. These authors demonstrated that not all tissues (spleen, thymus, and small intestine) had both species by RT-PCR analyses. Moreover, Frey et al. (2002) could only detect BVDV2 after the experimental challenge of pregnant heifers with BVDV-1 and BVDV-2 strains. Additionally, in that study BVDV-2 was also detected in all six calves born from the inoculated heifers.

It has been proposed that differences in the level of replication, as well as the tissue tropism, may exist between BVDV-1 and BVDV-2 (Brock and Chase, 2000; Bielefeldt-Ohmann et al., 2008). Moreover, BVDV-2 has been isolated more frequently in fetuses/calves delivered from dams inoculated with both species (Brock and Chase, 2000; Frey et al., 2002; Makoschey and Janssen, 2011).

Consequently, it has been suggested that BVDV-2 is more able to cross the placenta and infect the fetus in comparison to BVDV-1 (Bielefeldt-Ohmann et al., 2008; Passler et al., 2014).
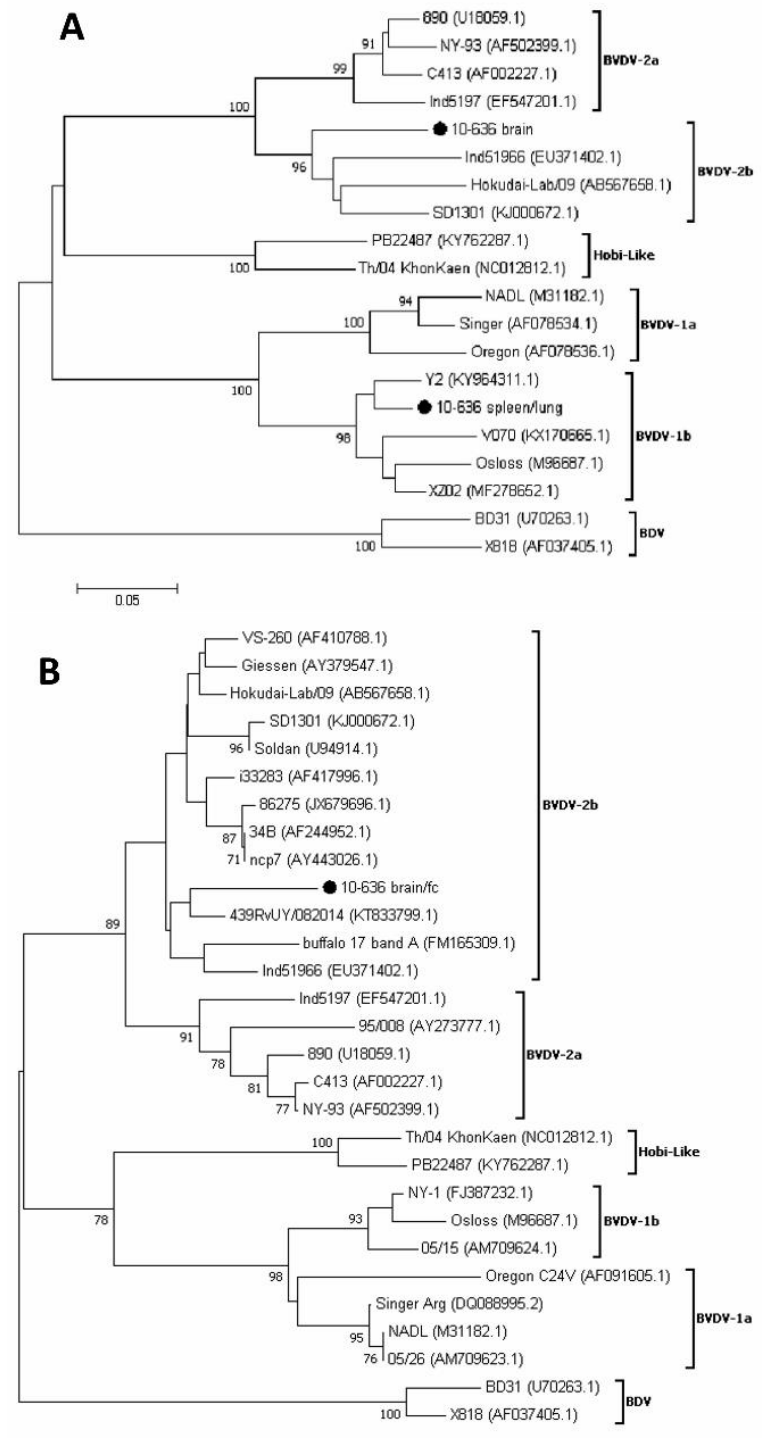

0.05

Fig. 1. Phylogenetic trees based on the partial nucleotide sequences of the genomic regions NS5B (A) and 5'UTR (B). Genetic distances were calculated using the Kimura-2 correction parameter and phylogenetic trees were constructed using the neighbor-joining method. Bootstrap values (1000 replicates) above $70 \%$ are shown. Nucleotide sequences from Border disease virus (bDV) were included for out-group rooting. BVDV strains reported in the current study are highlighted by dots. The GenBank accession number of each strain is indicated in brackets.

This experimental evidence supports our finding that BVDV-2 was more widely distributed in the tissues of the stillborn calf. In contrast, Paton et al. (1999) observed that BVDV-1 appeared to be more efficient than BVDV-2 at infecting the fetuses of seronegative ewes under experimental conditions. In the present study, whether differences in tissue distribution between both species is specific to these strains or is a general feature of BVDV-1 and BVDV-2 is uncertain. 
Broke and Chase (2000) have detected dual infections by RT-PCR from cell culture supernatants after viral isolation but not directly from tissue samples. Based on those results, in the current study viral isolation was attempted from all tissues after storage for 84 months at $-80^{\circ} \mathrm{C}$. Only BVDV -2 could be detected by nested multiplex RT-PCR from the cell culture supernatants (Table 1). Since both species were identified from lung, spleen and the cell culture supernatant of the spleen from the year 2010, it can be suggested that BVDV-1 was inactivated during storage but its RNA remains preserved. Interestingly, those findings also demonstrated that the viral-RNA could be stable in tissue samples for at least 84 months at $-80^{\circ} \mathrm{C}$. This fact was addressed by Ridpath et al. (2014) who have shown that BVDV nucleic acid was preserved in archived tissue samples maintained at $-80^{\circ} \mathrm{C}$ for at least 36 months under different storage conditions.

Phylogenetic analysis of the NS5B genomic region revealed the presence of subgenotypes BVDV-1b and BVDV-2b in the lung and spleen tissues from the stillborn calf. These results confirm the usefulness of the nested multiplex RT-PCR (Gilbert el al., 1999) for genotyping purposes. The NS5B genomic region has also been used for phylogenetic analyses of BVDV-1 and BVDV-2 strains (Nagai et al., 2004; Mishra et al., 2007, 2008), but in Argentina there are no previous reports on the phylogenetic study of the NS5B region among BVDV circulating strains. Most researches have characterized the 5'UTR and E2 regions (Jones et al., 2001; Odeón et al., 2003; Pecora et al., 2014). Nevertheless, the results of the phylogenetic analyses conducted with NS5B and 5'UTR regions agreed and confirmed that strain 10-636 brain/fc (BVDV-2) belonged to subgenotype $2 \mathrm{~b}$. This finding is quite remarkable since previous studies indicate that BVDV$1 \mathrm{a}$ and $-1 \mathrm{~b}$ are the predominant subgenotypes of Argentinean strains infecting ruminants (Jones et al., 2001; Odeón et al., 2003; Pecora et al., 2014), while BVDV-2 is less frequently report in this country. In bovine fetal and neonatal samples from Argentina, only a BVDV-2a strain recovered from an aborted fetus (Vilcek et al., 2004) and two BVDV-2b strains isolated from apparently healthy fetuses (Jones et al., 2001) were identified. This information indicates that no BVDV-2b was isolated previously from a stillborn calf in this country.

The detection of both BVDV-1 and BVDV-2 in the stillborn calf provides further evidence that dual infections can occur naturally. Viral co-infections are important as they may be a source of natural recombination between viruses, which can facilitate rapid genetic diversification, increased virulence or evasion of vaccine protection. While it was not investigated in this study, viral recombination has been reported for BVDV (Weber et al., 2015).

\section{Acknowledgments}

We thank our colleagues of the Specialized Veterinary Diagnostic Service of INTA Balcarce, Argentina.

\section{Conflict of interest}

The authors declare that there is no conflict of interest.

\section{References}

Ahn, B.C., Walz, P.H., Kennedy, G.A. and Kapil, S. 2005. Biotype, genotype, and clinical presentation associated with bovine viral diarrhea virus (BVDV) isolates from cattle. Intern. J. Appl. Res. Vet. Med. 3, 319-325.

Arenhart, S., Bauermann, F.V., Vogel, F.S.F., Weiblen, R. and Flores, E.F. 2010. Evidence of mixed persistent infections in calves born to cows challenged with a pool of bovine viral diarrhea virus isolates. Pesq. Vet. Bras. 30, 1053-1070.

Baker, J.C. 1995. The clinical manifestations of bovine viral diarrhea infection. Vet. Clin. North Am. Food Anim. Pract. 11, 425-445.

Bielefeldt-Ohmann, H., Tolnay, A.E., Reisenhauer, C.E., Hansen, T.R., Smirnova, N. and Van Campen, H. 2008. Transplacental infection with noncytopathic bovine viral diarrhoea virus types $1 \mathrm{~b}$ and 2: Viral spread and molecular neuropathology. J. Comp. Pathol. 138, 72-85.

Brock, K.V. and Chase, C.C.L. 2000. Development of a fetal challenge method for the evaluation of bovine viral diarrhea virus vaccines. Vet. Microbiol. 77, 209-214.

Evermann, J.F. and Ridpath, J.F. 2002. Clinical and epidemiologic observations of bovine viral diarrhea virus in the northwestern United States. Vet. Microbiol. 89, 129-139.

Frey, H.R., Eicken, K., Grummer, B., Kenklies, S., Oguzoglu, T.C. and Moennig, V. 2002. Foetal protection against bovine virus diarrhoea virus after two-step vaccination. J. Vet. Med. B. Infect. Dis. Vet. Public Health 49, 489-493.

Fulton, R.W., Saliki, J.T., Confer, A.W., Burge, L.J., d'Offay, J.M., Helman, R.G., Bolin, S.R., Ridpath, J.F. and Payton, M.E. 2000. Bovine viral diarrhea virus cytopathic and noncytopathic biotypes and type 1 and 2 genotypes in diagnostic laboratory accessions: clinical and necropsy samples from cattle. J. Vet. Diagn. Invest. 12, 33-38.

Gilbert, S.A., Burton, K.M., Prins, S.E. and Deregt, D. 1999. Typing of bovine viral diarrhea viruses directly from blood of persistently infected cattle by multiplex PCR. J. Clin. Microbiol. 37(6), 20202023.

Grooms, D.L. 2004. Reproductive consequences of infection with bovine viral diarrhea virus. Vet. Clin. North Am. Food Anim. Pract. 20, 5-19.

Hall, T.A. 1999. BioEdit: a user-friendly biological sequence alignment and analysis program for 
Windows 95/98/NT. Nucleic Acids Symp. Ser. 41, 95-98.

Jones, L.R., Zandomeni, R. and Weber, E.L. 2001. Genetic typing of bovine viral diarrhea virus isolates from Argentina. Vet. Microbiol. 81, 367375.

Kumar, S., Stecher, G. and Tamura, K. 2016. MEGA7: Molecular Evolutionary Genetics Analysis version 7.0 for bigger datasets. Mol. Biol. Evol. 33, 18701874.

Larska, M., Polak, M.P., Riitho, V., Strong, R., Belak, S., Alenius, S., Uttenthal, A. and Liu, L. 2011. Kinetics of single and dual infection of calves with an Asian atypical bovine pestivirus and a highly virulent strain of bovine viral diarrhea virus 1 . Comp. Immunol. Microbiol. Infect. Dis. 35, 381390.

Makoschey, B. and Janssen, M.G.J. 2011. Investigation of a dual fetal infection model with bovine viral diarrhoea viruses (BVDV)-1 and BVDV-2. Arch. Virol. 156, 1831-1833.

Mishra, N., Dubey, R., Rajukumar, K., Tosh, C., Tiwari, A., Pitale, S.S. and Pradhan, H.K. 2007. Genetic and antigenic characterization of bovine viral diarrhea virus type 2 isolated from Indian goats (Capra hircus). Vet. Microbiol. 124, 340-347.

Mishra, N., Rajukumar, K., Vilcek, S., Tiwari, S., Satav, J.S. and Dubey, S.C. 2008. Molecular characterization of bovine viral diarrhea virus type 2 isolate originating from a native Indian sheep (Ovies aries). Vet. Microbiol. 130, 88-98.

Nagai, M., Hayashi, M., Sugita, S., Sakoda, Y., Mori, M., Murakani, T., Ozawa, T., Yamada, N. and Akashi, H. 2004. Phylogenetic analysis of bovine viral diarrhea viruses using five different genetic regions. Virus Res. 99, 103-113.

Odeón, A.C., Risatti, G., Kaiser, G.G., Leunda, M.R., Odriozola, E., Campero, C.M. and Donis, R.O. 2003. Bovine viral diarrhea virus genomic associations in mucosal disease, enteritis and generalized dermatitis outbreaks in Argentina. Vet. Microbiol. 96, 133-144.

Passler, T., Riddell, K.P., Edmondson, M.A.,
Chamorro, M.F., Neill, J.D., Brodersen, B.W., Walz, H.L., Galik, P.K., Zhang, Y. and Walz, P.H. 2014. Experimental infection of pregnant goats with bovine viral diarrhea virus (BVDV) 1 or 2 . Vet. Res. 45, 38-48.

Paton, D.J., Sharp, G. and Ibata, G. 1999. Foetal crossprotection experiments between type 1 and type 2 bovine viral diarrhea virus in pregnant ewes. Vet. Microbiol. 64, 185-196.

Pecora, A., Malacari, D.A., Ridpath, J.F., Perez Aguirreburualde, M.S., Combessies, G., Odeón, A.C., Romera, S.A., Golemba, M.D. and Wigdorovitz, A. 2014. First finding of genetic and antigenic diversity in $1 \mathrm{~b}-\mathrm{BVDV}$ isolates from Argentina. Res. Vet. Sci. 96, 204-212.

Ridpath, J.F., Bolin, S.R. and Dubovi, E.J. 1994. Segregation of bovine viral diarrhea virus into genotypes. Virology 205, 66-74.

Ridpath, J.F., Neill, J.D., Chiang, Y.W. and Waldbillig, J. 2014. Stability of Bovine viral diarrhea virus 1 nucleic acid in fetal bovine samples stored under different conditions. J. Vet. Diagn. Invest. 26, 6-9.

Vilcek, S., Durkovic, B., Kolesarova, M. and Paton, D.J. 2005. Genetic diversity of BVDV: Consequences for classification and molecular epidemiology. Prev. Med. Vet. 72, 31-35.

Vilcek, S., Durkovic, B., Kolesarova, M., GreiserWilke, I. and Paton, D. 2004. Genetic diversity of international bovine viral diarrhoea virus (BVDV) isolates: identification of a new BVDV-1 genetic group. Vet. Res. 35, 609-615.

Vilcek, S., Herring, A.J., Herring, J.A., Nettleton, P.F., Lowings, J.P. and Paton, D.J. 1994. Pestiviruses isolated from pigs, cattle and sheep can be allocated into at least three genogroups using polymerase chain reaction and restriction endonuclease analysis. Arch. Virol. 136, 309-323.

Weber, M.N., Streck, A.F., Silveira, S., Sbaraini Mósena, A.C., Soares da Silva, M. and Canal, C.W. 2015. Homologous recombination in pestiviruses: Identification of three putative novel events between different subtypes/genogroups. Infect. Gen. Evol. 30, 219-224. 